\title{
Studies on the Replication of Reticuloendotheliosis Virus: Detection of Viral-Specific DNA Sequences in Infected Chick Cells
}

\author{
MARC S. COLLETT, ${ }^{1}$ RITA M. KIERAS, ${ }^{2}$ AND ANTHONY J. FARAS ${ }^{1}$ \\ Department of Microbiology, University of Michigan Medical School, Ann Arbor, Michigan 48104
}

Accepted January 23, 1975

\begin{abstract}
Infection of stationary chick embryo fibroblasts by reticuloendotheliosis virus (REV) is sensitive to cytosine arabinoside, an inhibitor of DNA synthesis. Furthermore, the majority of the nucleic acid sequences contained in the REV genome can be detected in infected cells in the form of DNA by RNA-DNA hybridization techniques. A small portion (ca. 5\%) of the $R E V$-specific sequences can be detected in uninfected chick embryo fibroblusts suggesting that these cells contain at least part of the REV genome as endogenous DNA sequences. These observations are consistent with an involvement of REV-specific proviral DNA as an intermediate in the replication of REV in chick embryo fibroblasts.
\end{abstract}

\section{INTRODUCTION}

The reticuloendotheliosis viruses (REV) are a group of avian RNA-containing viruses that exhibit several morphological and biochemical features similar to the avian leukosis-sarcoma virus (ALSV) complex (Zeigel et al., 1966; Baxter-Gabbard et al., 1971; Maldonado and Bose, 1971; Halpern et al., 1973; Maldonado and Bose, 1973; Kang and Temin, 1973). They do not however, share any serological relationship or genetic homology with the avian RNA tumor viruses and are therefore considered a separate group of avian viruses distinct from the ALSV complex (Theilen et al., 1966; Maldonado and Bose, 1971, 1973; Halpern et al., 1973; Kang and Temin, 1973; Mizutani and Temin, 1973; Purchase et $a l ., 1973)$. Infection of chick or duck embryo fibroblasts with REV results in some cell death; however, chronically infected cells, exhibiting no demonstrable cytopathological effects, can be established in cell culture (Bose and Levine, 1967;

${ }^{1}$ Present address: Department of Microbiology, University of Minnesota Medical School, Minneapolis, MN 55455.

${ }^{2}$ Present address: Department of Biochemistry, University of Pittsburgh, Pittsburgh, PA 15261.
Temin and Kassner, 1974; Faras, A. J., unpublished observations). Furthermore, recent studies have demonstrated that REV can transform bone marrow cells in vivo (Franklin et al., 1974).

The precise mechanism of infection of avian cells by REV has yet to be elucidated. The establishment of chronically infected carrier cultures in vitro and transformation of bone marrow cells in vivo suggest that these viruses may replicate through the agency of a DNA provirus similar to members of the ALSV complex (Temin, 1971a). However, we and others have been unable thus far to detect, in purified preparations of REV, an endogenous DNA-polymerase reaction in which the $70 \mathrm{~S}$ virion RNA acts as a template for the synthesis of DNA (Kang and Temin, 1974; Kieras and Faras, 1975). It was of considerable interest therefore to determine whether the $\mathrm{REV}$ group replicates through a DNA intermediate.

In this communication we report that REV replication is sensitive to cytosine arabinoside, an inhibitor of DNA synthesis, and actinomycin $\mathrm{D}$, an inhibitor of DNA-dependent RNA synthesis. These results are analogous to those obtained with 
members of the ALSV complex (Temin, 1963; Temin, 1967) and another member of the REV group, Trager duck spleen necrosis virus (Temin and Kassner, 1974). Furthermore, employing RNA-DNA hybridization with DNA in vast excess (Bishop, 1972; Melli et al., 1971), we have directly detected DNA sequences in REV-infected cells that are complementary to a large majority of the nucleotide sequences of the REV 70 S RNA genome. We conclude that the replication of $\mathrm{REV}$ in chronically infected chick cells proceeds through a DNA provirus intermediate. While this manuscript was in preparation, Kang and Temin reported similar observations with Trager duck spleen necrosis virus (TDSNV) (Kang and Temin, 1974).

\section{MATERIALS AND METHODS}

Cells and virus. Embryonated chick eggs, negative for avian leukosis virus group-specific antigen, were obtained from SPAFAS, Roanoke, IL; embryonated Pekin duck eggs were obtained from the Tulip City Duck Farm, Holland, MI. B77 strain (subgroup C) of Rous sarcoma virus (RSV) was propagated in chick embryo fibroblasts and purified as previously described (Faras and Dibble, 1975). The Cook strain of REV, presumably derived from the original virus isolate of Twiehaus (strain T; Theilen, 1966) was a kind gift from Dr. G. Purchase. REV was propagated in chick embryo fibroblasts. Although infection of chick cells with REV resulted in some cell death, many of the infected cells exhibited no apparent cytopathic effects and were maintained through several passages. The cells appeared to be chronically infected with REV since they continually produced virus. These cells were the source of REVinfected cell DNA.

Preparation of REV and RSV 70 S RNA. ${ }^{32} \mathrm{P}$-labeling of RSV and REV-RNA was accomplished by previously published procedures (Dahlberg et al., 1974; Faras and Dibble, 1975). Briefly, infected cultures were washed with phosphate-free medium and then labeled with $1 \mathrm{mCi}$ of carrier-free $\left.{ }^{32} \mathrm{P}\right]$ orthophosphate per $\mathrm{ml}$. Virus was harvested at $24-\mathrm{hr}$ intervals and stored at $-70^{\circ}$. Virus was purified by pelleting through a $25 \%$ sucrose cushion in an SW 27 rotor at $27,000 \mathrm{rpm}$ for $2.5 \mathrm{hr}$ at $4^{\circ}$. The virus pellets were resuspended in STE $(0.1$ $M \mathrm{NaCl}, 0.02 M$ Tris-HCl, $\mathrm{pH} 7.4$, and $0.01 M$ EDTA), treated with $0.5 \%$ sodium dodecyl sulfate (SDS) and $500 \mu \mathrm{g} / \mathrm{ml}$ of Pronase for $30 \mathrm{~min}$ at $37^{\circ}$, and extracted three times with cold STE-saturated phenol. Viral $70 \mathrm{~S}$ RNA was further fractionated from the low molecular weight RNAs by rate-zonal sedimentation in 15-30\% sucrose in an SW 41 rotor at $41,000 \mathrm{rpm}$ for $3 \mathrm{hr}$ at $4^{\circ}$. The specific activity of the ${ }^{32} \mathrm{P}$-labeled $70 \mathrm{~S}$ RNA was approximately $3-4 \times 10^{6} \mathrm{cpm} / \mu \mathrm{g}$ and was estimated either directly by determining the $A_{260}$ of the $\mathrm{P}^{32}$-labeled $70 \mathrm{~S} \mathrm{RNA}$ preparation or indirectly by determining the specific activity of total cytoplasmic RNA extracted from the virus-producing cells. In our hands the specific activities obtained by either method were comparable.

All preparations of ${ }^{32} \mathrm{P}$-labeled REVRNA were assayed for the presence of avian leukosis virus-specific sequences by measuring the extent of homology between the REV genome and the genomes of the ALSV complex by molecular hybridization. This was accomplished by reacting DNA complementary to either the RSV or RAV-2 viral genome (cDNA) with ${ }^{32} \mathrm{P}$-labeled REV 70 S RNA under conditions that permit saturation of most, if not all, of the complementary nucleotide sequences in the RNA (Garapin et al., 1973). The extent of hybridization (sequence homology) was obtained by determining the proportion of the labeled viral RNA which became resistant to pancreatic ribonuclease (Duesberg and Canaani, 1970; Garapin et al., 1973). The cDNA utilized in these experiments was prepared as described previously (Garapin et al., 1973). The reaction mixtures contained $300 \mu \mathrm{g} / \mathrm{ml}$ of virus protein, $0.1 M$ Tris- $\mathrm{HCl}, \mathrm{pH} 8.1$; dGTP, dCTP, dATP, and $\left[{ }^{3} \mathrm{H}\right]$ TTP $(300 \mathrm{cpm} / \mathrm{pmole})$, each at 5 $\times 10^{-5} \mathrm{M} ; 0.01 \mathrm{M} \mathrm{MgCl}_{2} ; 2 \% \beta$-mercaptoethanol; $0.01 \%(\mathrm{v} / \mathrm{v})$ Nonidet-P40; and actinomycin $\mathrm{D}(100 \mu \mathrm{g} / \mathrm{ml})$ to promote a more uniform transcription of the template RNA into DNA. Reactions were carried out at $37^{\circ}$ for $4 \mathrm{hr}$, then extracted with 
SDS-phenol (Faras et al., 1972). Nucleic acids were recovered by precipitation with ethanol, treated with $0.3 \mathrm{M} \mathrm{NaOH}$ at $37^{\circ}$ for $16 \mathrm{hr}$ to remove viral RNA, neutralized, and precipitated again with ethanol. Conditions for hybridization are given in the legend to Fig. 1. As depicted in Fig. 1, no measurable ribonuclease-resistant hybrids could be detected between RSV or RAV-2 cDNA and REV $70 \mathrm{~S}$ RNA indicating the lack of ALSV-specific sequences in our preparations of REV-RNA. These results establish the purity of the REV 70 S RNA employed in the hybridization experiments

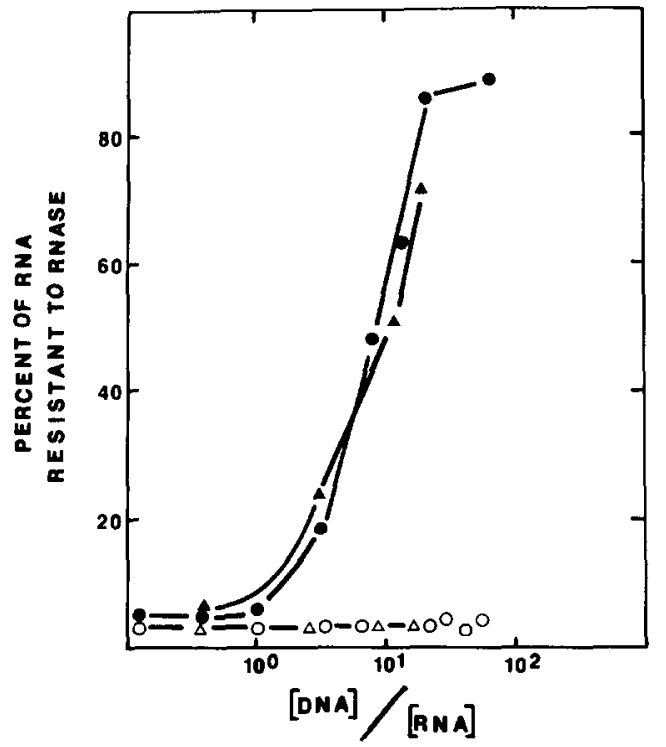

FIG. 1. Sequence homology between the $70 \mathrm{~S}$ RNA genomes of REV and RSV. ${ }^{3} \mathrm{H}$-labeled cDNA, pre-। pared from detergent-disrupted RSV (Schmidt-Ruppin strain) and Rous-associated virus-2(RAV-2) under reaction conditions described in Materials and Methods, was hybridized to ${ }^{32} \mathrm{P}$-labeled $70 \mathrm{~S}$ RNA of REV and their respective ${ }^{32} \mathrm{P}$-labeled 70 S RNA's as follows. Approximately $0.5^{-1} \mathrm{ng}$ of ${ }^{32} \mathrm{P}$-labeled RNA and varying amounts of ${ }^{3} \mathrm{H}$-labeled DNA in $10 \mu \mathrm{l}$ of annealing buffer $(0.6 \mathrm{M} \mathrm{NaCl}, 0.01 M$ EDTA, $0.02 M$ Tris- $\mathrm{HCl}, \mathrm{pH}, 7.4)$ were sealed in $30-\mu$ l glass capillary tubes and incubated for $68 \mathrm{hr}$ at $68^{\circ}$. The extent of hybridization was measured by hydrolysis with pancreatic ribonuclease as described in Materials and Methods. The results are plotted as a function of the ratio of DNA and RNA present in each sample (Garapin et al., 1973). Symbols: - RSV-specific cDNA hybridized to RSV 70 S RNA; O, RSV-specific cDNA hybridized to REV $70 \mathrm{~S}$ RNA; $\Delta$, RAV 2-specific cDNA hybridized to RAV-2 70 S RNA; $\triangle$, RAV-2-specific cDNA hybridized to REV 70 S RNA. presented in this communication (Tables 1 and 2 and Fig. 4) and further document the lack of sequence homology between these two groups of avian RNA-containing viruses (Kang and Temin, 1973).

Preparation of cell DNA. Cellular DNA was prepared by previously published methods (Varmus et al., 1973). Cells were lysed with $0.5 \%$ SDS and incubated for $2 \mathrm{hr}$ at $37^{\circ}$ with $500 \mu \mathrm{g} / \mathrm{ml}$ of Pronase (self-digested for $2 \mathrm{hr}$ at $37^{\circ}$ prior to use). The disrupted cells were extracted with phenol twice at room temperature, and the nucleic acids were precipitated with 2 vol of ethanol. The nucleic acids were recovered by centrifugation, resuspended in 0.02 $M$ Tris-HCl, pH 7.4, 0.01 $M$ EDTA, and treated for $4 \mathrm{hr}$ at $37^{\circ}$ with $100 \mu \mathrm{g} / \mathrm{ml}$ of pancreatic ribonuclease (boiled for $10 \mathrm{~min}$ to inactivate deoxyribonuclease). The sample was further incubated with $100 \mu \mathrm{g} / \mathrm{ml}$ of Pronase for $30 \mathrm{~min}$ at $37^{\circ}$ and then subjected to two phenol extractions at room temperature. At this stage the DNA was either precipitated with ethanol or extensively dialyzed against $1 \times \mathrm{SSC}(0.15$ $M \mathrm{NaCl}$ plus $0.015 M$ sodium citrate). The $A_{260} / A_{280}$ ratio of DNA prepared in this manner was invariably greater than 1.85 . Prior to hybridization all DNA was fragmented to a length of 300-400 nucleotides by limited depurination as described previously (McConaughy and McCarthy, 1967; Neiman, 1972). The concentration of DNA was adjusted to $2 \mathrm{mg} / \mathrm{ml}$ in $0.1 \times \mathrm{SSC}$ and the $\mathrm{pH}$ adjusted to 4.3 with sodium acetate. The DNA was then incubated at $70^{\circ}$ for $90 \mathrm{~min}$, the $\mathrm{pH}$ was adjusted to 11.0 with $\mathrm{NaOH}$, and the sample was further incubated at $50^{\circ}$ for $10 \mathrm{~min}$ before neutralizing to $\mathrm{pH}$ 7.0. DNA was precipitated with ethanol and resuspended in $1 \mathrm{~m} M$ EDTA.

Hybridization conditions. Details of the hybridization conditions are presented in the legends to the tables and figures. Annealing is generally performed in $0.6 \mathrm{M}$ $\mathrm{NaCl}, 0.02 M$ Tris-HCl (pH 7.4), $0.002 M$ EDTA and $0.05 \%$ SDS at $68^{\circ}$. Volumes of $30 \mu 1$ or less were incubated in sealed capillary pipettes, and larger volumes were incubated in glass tubes under a layer of mineral oil. Extent of hybridization was determined by treatment of the samples 
with $50 \mu \mathrm{g}$ of pancreatic ribonuclease per $\mathrm{ml}$ in $2 \times \mathrm{SSC}$ at $37^{\circ}$ for $45 \mathrm{~min}$.

\section{RESULTS}

Effects of an Inhibitor of DNA Synthesis on Replication of REV in Chick Embryo Fibroblasts

We have investigated the effects of an inhibitor of DNA synthesis on the replication of $\mathrm{REV}$ in an effort to determine whether virus-specific DNA synthesis is required for $\mathrm{REV}$ infection. It has been previously reported that the rate of multiplication of chick embryo fibroblasts in vitro is dircetly determined by the amount of serum in the medium (Temin, 1969) and that, in the absence of serum, the cells do not divide but remain stationary (Temin, 1971b). These stationary cell cultures remain susceptible to infection with mem- bers of both the ALSV and REV groups of viruses (Temin, 1971a; Temin and Baltimore, 1972; Temin and Kassner, 1974; Fig. 2). The efficiency of infection of stationary chick cells with REV or RSV was similar to the infection of the same number of normally dividing chick embryo fibroblasts indicating that the stationary cultures were not inhibitory to REV or RSV replication (data not shown). If these stationary chick cultures are treated with $2 \times$ $10^{-4} M$ cytosine arabinoside and infected with either REV or RSV, considerable inhibition of virus production is observed (Figs. 2a and b), suggesting that viralspecific DNA synthesis is required for the replication and establishment of infection of chick cells with both REV and RSV.

Virus production by REV-infected cells was also dramatically inhibited $(>99 \%)$

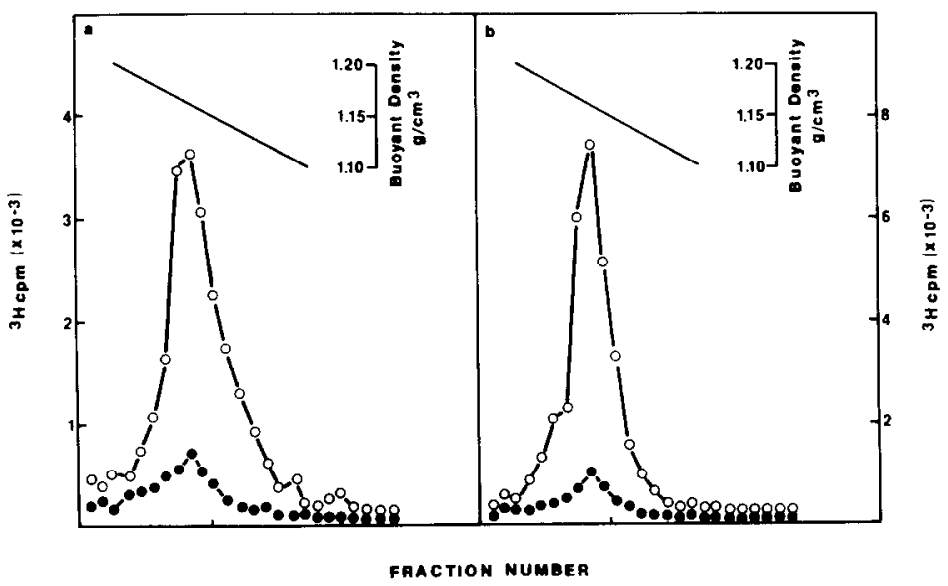

FIG. 2. Effect of cytosine arabinoside upon infection of chick embryo fibroblasts by REV and RSV. Cultures of stationary chick embryo fibroblasts (Temin, 1971) were exposed to REV or RSV and incubated for $1 \mathrm{hr}$ at $37^{\circ}$. The inoculum was removed and $5 \mathrm{ml}$ of medium 199 , devoid of calf serum but containing $2 \times 10^{-4} M$ cytosine arabinoside, was added to the cultures. After $18 \mathrm{hr}$ at $37^{\circ}$ the medium was removed and replaced with medium containing $4 \%$ calf serum but lacking cytosine arabinoside. After $48 \mathrm{hr}$ of incubation at $37^{\circ}$, cultures were labeled with $30 \mu \mathrm{Ci} / \mathrm{ml}$ of $\left[{ }^{3} \mathrm{H}\right.$ ]uridine and incubated an additional $24 \mathrm{hr}$ at $37^{\circ}$. Control experiments consisted of infecting cells with REV or RSV under identical conditions, described above, except that cytosine arabinoside was omitted from the medium. Cytosine arabinoside appeared to be somewhat toxic $(60 \%)$ to cells at the concentrations employed (Temin and Kassner, 1974). However, the drug had no effect on the production of REV from chronically infected, nondividing cells. Furthermore, virus production was normalized to the number of viable cells remaining in control and treated cultures. Virus production was assayed by isopycnic centrifugation. Exactly $5 \mathrm{ml}$ of $\left[{ }^{3} \mathrm{H}\right]$ uridine-labeled medium was layered onto a 2 -ml solution of $15 \%$ sucrose which overlayed a $5-\mathrm{ml} 25-55 \%$ sucrose gradient. The virus was centrifuged at $41,000 \mathrm{rpm}$ in an SW 41 rotor for $2.5 \mathrm{hr}$ at $4^{\circ}$. Fractions were collected, analyzed for refractive indexes, and precipitated with $10 \%$ trichloroacetic acid. Acid-precipitable radiolabel was collected onto glass-fiber filters and counted in a Beckman scintillation spectrometer. Data are presented as ${ }^{3} \mathrm{H}$ cpm per $2 \times 10^{5}$ cells. (a), RSV-infected chick embryo fibroblasts; (b), REV-infected chick embryo fibroblasts. Symbols: $O$, cells infected with virus in the absence of cytosine arabinoside;, cells infected with virus in the presence of $2 \times 10^{-4} M$ cytosine arabinoside. 
when actinomycin $\mathrm{D}$ was included in the medium suggesting that transcription of DNA is also required for the replication of REV (Fig. 3).

\section{Detection of REV-Specific DNA Sequences in Infected Chick Cells}

We have employed hybridization techniques, which allow nearly complete hybridization of complementary RNA with DNA from eukaryotes (Bishop et al., 1972; Melli et al., 1971), in an attempt to detect REV-specific DNA sequences in chick embryo fibroblasts subsequent to infection of cell cultures with REV. 'The extent of hybridization between an excess of singlestranded DNA fragments prepared from uninfected chick embryo fibroblasts, REVinfected chick embryo fibroblasts, and uninfected duck embryo fibroblasts and

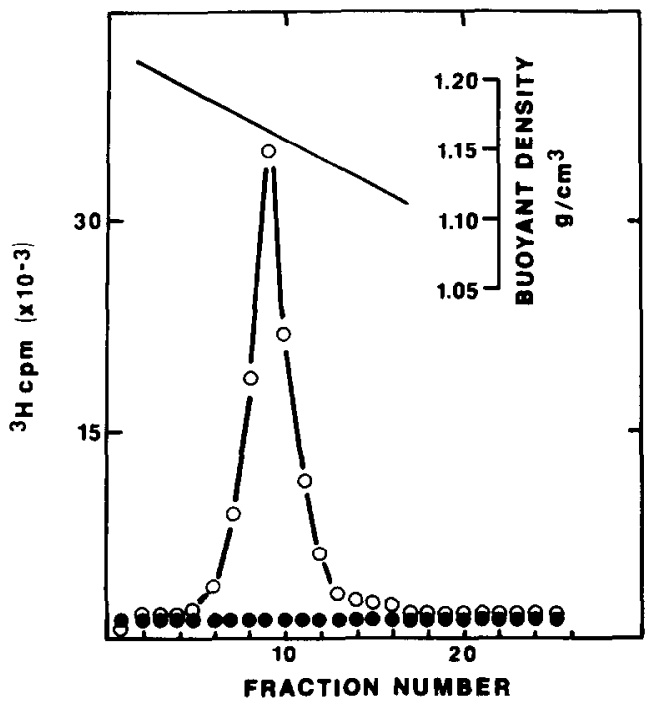

Fic. 3. Fffect of actinomycin $D$ upon production of REV by infected chick embryo fibroblasts. REVinfected and producing cultures of chick embryo fibroblasts were exposed to $2 \mu \mathrm{g} / \mathrm{ml}$ of actinomycin D at $37^{\circ}$. After $2 \mathrm{hr}, 20 \mu \mathrm{Ci} / \mathrm{ml}$ of $\left[{ }^{3} \mathrm{H}\right.$ ] uridine was added to the medium and the cultures were incubated for an additional $24 \mathrm{hr}$. The $\left[{ }^{3} \mathrm{H}\right]$ uridine-containing medium was harvested and $5 \mathrm{ml}$ were assayed for virus by isopycnic centrifugation as described in Fig. 2. Control cultures were subjected to identical manipula. tions except that actinomycin D was omitted from the medium. Symbols: O, control cultures; O, REVinfected cells incubated in the presence of $2 \mu \mathrm{g} / \mathrm{ml}$ of actinomycin D. radioactive REV $70 \mathrm{~S} R \mathrm{RA}$ is presented in Table 1.

Whereas no more than $10 \%$ of the REV viral RNA formed ribonuclease-resistant hybrids when the hybridization was performed in the presence of a large excess of DNA from uninfected chick embryo fibroblasts, approximately $78 \%$ of the REV viral RNA sequences became ribonucleaseresistant when hybridization was performed in the presence of DNA isolated from REV-infected chick embryo fibroblasts. Under similar hybridization conditions, $75 \%$ of the RSV 70 S RNA genome forms ribonuclease-resistant hybrids with DNA from RSV-transformed chick cells (Neiman, 1972; Varmus et al., 1974; Table 1 ), whereas only $30 \%$ of the RSV sequences can be detected in uninfected chick cells (Neiman, 1972, 1973; Varmus et al., 1974; Table 1). Therefore, as is the case with the avian RNA tumor viruses, most, if not all, of the genetic sequences contained in the REV-RNA genome are present in the form of DNA subsequent to infection of chick cells with the virus.

The detection of appreciable (ca. 30\%)

TABLE 1

Hybridization of REV and RSV 70 S RNA To Uninfected and Infected Avian Cell DNA ${ }^{a}$

\begin{tabular}{|c|c|c|}
\hline 70 S RNA & $\begin{array}{l}\text { Source of } \\
\text { cellular DNA }\end{array}$ & $\begin{array}{c}\text { Percent } \\
\text { hybridization }\end{array}$ \\
\hline REV & Uninfected duck & 3.6 \\
\hline REV & Uninfected chick & 9.7 \\
\hline REV & REV-infected chick & 78.0 \\
\hline RSV & Uninfected duck & 1.7 \\
\hline RSV & RSV-infected duck & 78.5 \\
\hline RSV & Uninfected chick & 28.0 \\
\hline RSV & RSV-infected chick & 75.0 \\
\hline
\end{tabular}

a ${ }^{2}$ P-labeled $70 \mathrm{~S}$ RNA $(2,000 \mathrm{cpm}, 0.5 \mathrm{ng})$ from either REV or RSV was incubated at $68^{\circ}$ in a solution containing $0.6 \mathrm{M} \mathrm{NaCl}$ and a vast excess of fragmented, denatured cellular DNA $(10 \mathrm{mg})$ to $C_{0} t$ values of approximately $3 \times 10^{4}$ mole sec/liter. Extent of hybridization was determined by resistance to pancreatic ribonuclease as described in Materials and Methods.

- The percent hybridization was corrected for the intrinsic ribonuclease-resistance of the RNA (5\%) and nonspecific interaction of viral RNA with calf thymus DNA (6\%). Data are presented as the averages of three or more separate determinations. 
hybridization of the RSV genome to uninfected chick cell DNA is consistent with reports from other laboratories (Neiman, 1972; Neiman, 1973; Schincariol and Joklik, 1973; Varmus et al., 1974) and further documents the presence of RSV-specific endogenous sequences in uninfected chick embryo fibroblasts. In contrast to RSV, only a small portion (ca. 10\%) of the REV-RNA genome forms ribonucleaseresistant duplexes with uninfected chick cell DNA. In view of the low levels of duplex formation observed between REV 70 S RNA and uninfected chick cell DNA, the specificity of hybridization was determined by competition experiments. ${ }^{32} \mathrm{P}$ labeled REV 70 S RNA was hybridized to uninfected chick cell DNA at $C_{0} t\left(C_{0}\right.$ is the concentration of DNA nucleotides in moles/liter, and $t$ is time in seconds) (Britten and Kohne, 1968) values of approximately $2 \times 10^{4}$ mole sec/liter in the presence of a 10,000-fold excess of either unlabeled REV 70 S RNA, RSV 70 S RNA, or HeLa cell ribosomal RNA. From the results presented in Table 2, it appears that both unlabeled RSV $70 \mathrm{~S}$ RNA and HeLa cell ribosomal RNA reduce duplex formation between ${ }^{32} \mathrm{P}$-labeled REV $70 \mathrm{~S}$ RNA and uninfected chick cell DNA to $4-5 \%$, indicating that at least part of the ribonuclease-resistant, ${ }^{32} \mathrm{P}$-labeled $\mathrm{REV}$ RNA observed was probably a result of nonspecific interaction between the nucleic acids present in the hybridization mixtures. However, complete competition of ${ }^{32} \mathrm{P}$. labeled REV-RNA was observed when unlabeled REV 70 S RNA was included in the hybridization mixtures indicating that approximately $4-5 \%$ of the ribonuclease-resistant hybrids formed, when radioactive REV $70 \mathrm{~S}$ RNA is reacted with uninfected chick DNA, are REVspecific. It therefore appears that uninfected chick cells contain approximately $5 \%$ of the REV genome as REV-specific endogenous DNA sequences.

No ribonuclease-resistant hybrids were observed when radioactive RSV 70 S RNA was hybridized to uninfected duck DNA, a result consistent with recent reports from other laboratories (Varmus et al., 1973, 1974; Kang and Temin, 1974). However we
TABLE 2

Competition Hybridization Between ${ }^{32}$ P-Labeled REV 70 S RNA AND UNLABELED REV, RSV OR Ribosomal RNA for Duplex Formation with Uninfected Chick Cell DNA ${ }^{a}$

\begin{tabular}{clc}
\hline DNA & \multicolumn{1}{c}{$\begin{array}{c}\text { Competing } \\
\mathrm{RNA}^{b}\end{array}$} & $\begin{array}{c}\text { Percent } \\
\text { hybridi- } \\
\text { zation }\end{array}$ \\
\hline Uninfected chick & None & 10.0 \\
Uninfected chick & REV 70 S RNA & 0 \\
Uninfected chick & RSV 70 S RNA & 5.0 \\
Uninfected chick & HeLa ribosomal & 4.0 \\
& RNA & \\
\hline
\end{tabular}

${ }^{a}$ Hybridization between ${ }^{32} \mathrm{P}$-labeled REV $70 \mathrm{~S}$ RNA and uninfected chick DNA in vast excess was performed essentially as described in Table $1 . C_{0} t$ values of $2 \times 10^{4}$ mole sec/liter were achieved in all cases. The percent hybridization was corrected for the intrinsic ribonuclease-resistance of the RNA and nonspecific interaction of viral RNA with calf thymus DNA $(11 \%)$. Each experiment represents an average of duplicate samples.

- Competition-hybridization was performed by including $5 \mu \mathrm{g}$ of unlabeled REV $70 \mathrm{~S}$ RNA, RSV $70 \mathrm{~S}$ RNA, or HeLa ribosomal RNA in the hybridization mixtures described in footnote $a$.

have routinely observed low levels $(2-4 \%)$ of duplex formation between REV $70 \mathrm{~S}$ RNA and uninfected duck DNA (Table 1). Further studies employing competition-hybridization experiments will be required before the nature of these duplex structures can be determined.

\section{Estimation of the Number of REV-Specific DNA Genome Equivalents in Infected Cells}

Figure 4 illustrates the kinetics of hybridization between an excess of uninfected and REV-infected chick cell DNA and radioactive REV $70 \mathrm{~S}$ RNA plotted as a function of $C_{0} t$. Approximately $75 \%$ of the viral RNA formed ribonuclease-resistant hybrids with REV-infected chick cell DNA at $C_{0} t$ values of $3 \times 10^{4} \mathrm{~mole}$ sec/ liter. Similarly, relatively high $C_{0} t$ values are also required for the reassociation of unique-sequence chick cell DNA presumably present at a frequency of one copy per haploid genome (Britton and Kohne, 1968; Neiman, 1972). Although one must take into account the apparent differences between the rates of RNA-DNA hybridiza- 


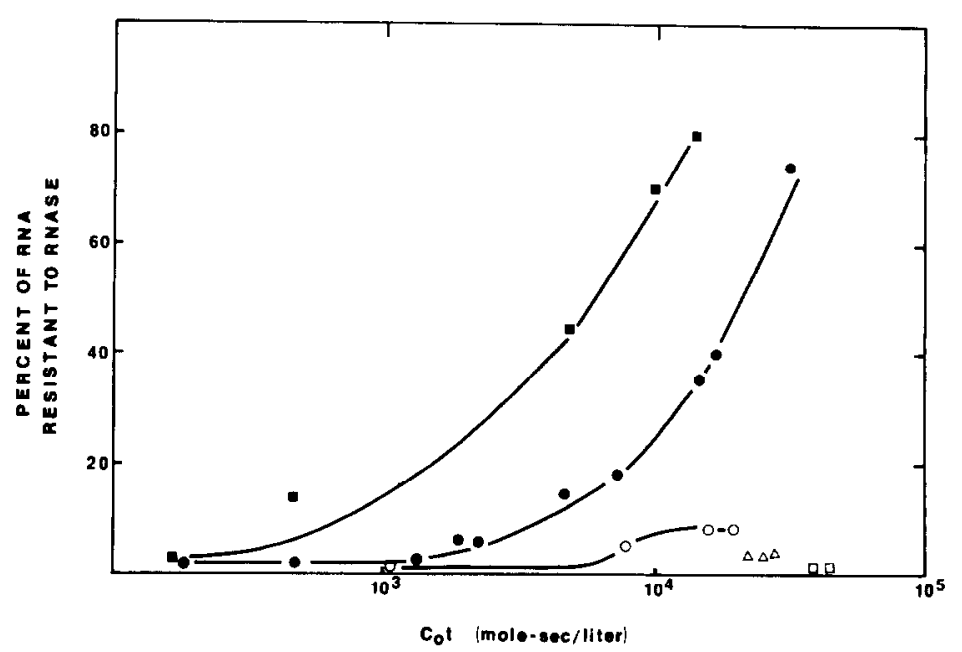

FIG. 4. Kinetics of hybridization of ${ }^{32} \mathrm{P}$-labeled REV $70 \mathrm{~S}$ RNA with uninfected and REV-infected chick embryo fibroblast DNA. ${ }^{32} \mathrm{P}$-labeled $70 \mathrm{~S}$ RNA from either REV or RSV (2,000 cpm, $\left.0.5 \mathrm{ng}\right)$ was incubated at $68^{\circ}$ in a solution containing $0.6 \mathrm{M} \mathrm{NaCl}$ and various concentrations of an excess of DNA $(160 \mu \mathrm{g} / \mathrm{ml}-11 \mathrm{mg} / \mathrm{ml})$ to achieve the desired $C_{0} t$ values for a $50 \mathrm{hr}$ incubation period. Extent of hybridization was determined by pancreatic ribonuclease digestion as described in Table 1 . The extent of hybridization was corrected for background ribonuclease-resistance and nonspecific interaction of viral RNA with calf thymus DNA (11\%). Symbols: 9 , REV 70 S RNA hybridized with REV-infected chick embryo fibroblast DNA; O, REV 70 S RNA hybridized with uninfected chick embryo fibroblast DNA; $\triangle$, REV 70 S RNA hybridized with uninfected duck embryo fibroblast DNA; $\square$, RSV 70 S RNA hybridized with RSV-infected duck embryo fibroblast DNA; $\square$, RSV 70 S RNA hybridized with uninfectcd duck embryo fibroblast DNA.

tion and DNA-DNA reassociation (Bishop, 1972; Melli et al., 1972), the observed rate of hybridization of REV-RNA and infected chick DNA suggests that the REV-specific DNA sequences are present at a low frequency per cell. To directly test this possibility we have compared the rate of hybridization of REV $70 \mathrm{~S}$ RNA and REVinfected chick cell DNA with that of RSV 70 S RNA and RSV-transformed duck cell DNA which contains approximately four to six copies of RSV-specific DNA sequences per diploid genome (Varmus, 1973). The data in Fig. 4 indicate that REV $70 \mathrm{~S}$ RNA hybridizes more slowly to REV-infected chick cell DNA than does RSV 70 S RNA to RSV-infected duck cell DNA, suggesting that the REV sequences are present in relatively low copy number. An approximate estimate of the frequency of REVspecific DNA sequences present in REVinfected chick cells is one to two copies per diploid cell.

\section{DISCUSSION}

We have previously demonstrated that virions of REV lack an endogenous RNA- directed DNA-polymerase activity characteristic of most, if not all, avian RNA tumor viruses (Kieras and Faras, 1975). Apparently the virion-associated DNA polymerase is unable to utilize the viral $70 \mathrm{~S}$ RNA as template for the in vitro synthesis of DNA. In view of these observations it was of considerable importance to determine whether reverse transcription of the REV genome occurs in vivo during infection of chick cells with REV.

In this report we present data indicating that DNA synthesis, presumably REVspecific, is required for the establishment of infection of chick cells with REV. Furthermore, we have directly detected REVspecific sequences in DNA extracted from chick embryo fibroblasts infected with REV. These results are analogous to those recently reported on another member of the REV group by Temin and co-workers (Temin and Kassner, 1974; Kang and Temin 1974) and lend support to the involvement of a DNA intermediate in the replication of $R E V$. Additional support was obtained by the demonstration that DNA extracted from REV-infected cells was in- 
fectious (Cooper and Temin, 1974).

Although the specific hybridization techniques employed in our studies provide one with the best minimal estimate to date of the fraction of the viral genome present in cell DNA (Bishop, 1972; Melli et al., 1972; Neiman, 1972, 1973; Varmus et al., 1974), we have been unable to anneal more than $75-80 \%$ of the REV-RNA to infected-cell DNA. This limitation is apparently a function of several factors including the unfavorable rate of RNA-DNA as opposed to DNA-DNA annealing (Bishop, 1972; Melli et al., 1972), the thermal lability of the RNA, and the prolonged incubation times required to achieve high $C_{0} t$ values (Melli et al., 1972). We have also attempted to determine the relative frequency at which the REV-specific DNA sequences are present in infected cells by comparing the rates of hybridization of REV and RSV $70 \mathrm{~S}$ RNA to REV-infected chick and RSVinfected duck cell DNA, respectively. These studies suggested that REV-specific DNA sequences are present in relatively low frequency (one to two copies) in infected cells. This is a rough estimate since the precise determinations of frequency number by such procedures are difficult because of the possible variability of annealing rates among RNA species (Strauss and Bonner, 1972). Furthermore, we cannot exclude the possibility at this time that the low estimate of copy number in REV-infected cells reflects the inability to infect every cell with virus. Therefore, a more extensive analysis of the quantitation of REV-specific DNA sequences is currently under investigation in our laboratory.

Although most of the REV genome can be detected in infected cells, only $4-5 \%$ of $\mathrm{REV}$-specific sequences can be detected in uninfected chick cells. This is in contrast to members of the ALSV complex which appear to share approximately $30-40 \%$ of their genome with uninfected chick cell DNA under similar conditions of hybridization (Neiman, 1972, 1973; Schincariol and Joklik, 1973; Varmus et al., 1974; Table 1). Nevertheless, these low levels of REV-specific endogenous DNA sequences present in uninfected chick cell DNA have been observed consistently with several different preparations of chick DNA. Since the bulk of the REV $70 \mathrm{~S}$ RNA genome utilized in these experiments exhibits no detectable sequence homology with either avian leukosis or sarcoma virus $70 \mathrm{~S}$ RNA (Fig. 1) and no competition of REV-RNA for duplex formation was observed with RSV 70 S RNA (Table 2), it is unlikely that the REV-specific sequences found in uninfected chick cell DNA are related to avian RNA tumor viruses. Kang and Temin have observed slightly more homology between the TDSNV genome and uninfected chick cell DNA (Kang and Temin, 1974). Although we presently cannot explain the reason for these differences, they may at most, reflect minor sequence differences between the genomes of $\operatorname{REV}(T)$ and TDSNV.

We do not, as yet, know the status of these REV proviral DNA sequences in infected cells. We are currently attempting to determine whether they are integrated into the chick cell genome DNA, as is the case with the avian RNA tumor viruses (Varmus et al., 1973). Although the REV DNA-polymerase is incapable of transcribing the REV genome in vitro, it appears from these studies that the process of reverse transcription does in fact occur in vivo. It will be of considerable interest to determine if a host cell function is required to facilitate the transcription of the REV genome subsequent to infection of cells with REV.

\section{ACKNOWLEDGMENTS}

We thank C. Collins and W. Folk for critical reading of this manuscript and $\mathrm{N}$. Dibble and $\mathrm{C}$. Fox for excellent technical assistance. We are also grateful for the gift of cytosine arabinoside from C. Shipman. This investigation was supported by Public Health Service Research Grant No. CA 14790-02 from the National Cancer Institute, and Grant No. DRG-1268 from the Damon Runyon-Walter Winchell Memorial Fund for Cancer Research. M.S.C. was supported by a Horace H. Rackham predoctoral fellowship.

\section{REFERENCES}

Baxter-Gabrart, K. L., Campeell, W. F., Padgett, F., Raitano-Fenton, A., and Levine, A. (1971). Avian reticuloendotheliosis (strain T). II. Biochemical and biophysical properties. Avian Dis. 15, 850-862. 
Bishop, J. O. (1972). Molecular hybridization of ribonucleic acid with a large excess of deoxyribonucleic acid. Biochem. J. 126, 171-185.

Bose, H. R., and Levine, A. S. (1967). Replication of the reticuloendotheliosis virus (strain $\mathrm{T}$ ) in chicken embryo cell culture. J. Virol. 1, 1117-1121.

Britten, R. J., and Kohne, D. E. (1968). Repeated sequences in DNA. Science 161, 520540.

Cooper, G. M., and Temin, H. M. (1974). Infectious Rous sarcoma virus and reticuloendotheliosis virus DNA's. J. Virol. 14, 1132-1141.

Dahleerg, J. E., Sawyer, R. C., Taylor, J. M., Faras, A. J., Levinson, W. E., Goodman, H. M., and Bishop, J. M. (1974). Transcription of DNA from the 70 S RNA of Rous sarcoma virus. I. Identification of a specific $4 \mathrm{~S}$ RNA which serves as primer. $J$. Virol. 13, 1126-1133.

Duesberg, P. H., and Canaani, E. (1970). Complementarity between Rous sarcoma virus RNA and the in vitro synthesized DNA of the virusassociated DNA polymerase. Virology 42, 783-788.

Faras, A. J., Taylor, J. M., McDonnell, J. P., Levinson, W. E., and Bishop, J. M. (1972). Purification and characterization of the deoxyribonucleic acid polymerase associated with Rous sarcoma virus. Biochemistry 11, 2334-2342.

FARAS, A. J., and DibBle, N. A. (1975). RNA-directed DNA synthesis by the DNA polymerase of Rous sarcoma virus: Structural and functional identification of $4 \mathrm{~S}$ primer RNA in uninfected cells. Proc. Nat. Acad. Sci. USA in press.

Franklin, R. B., Maldonado, R. L., and Bose, H. R. (1975). Isolation and characterization of reticuloendotheliosis virus transformed bone marrow cells. Intervirology 3, 342-352.

Garapin, A. C., Varmus, H. E., Faras, A. J., Levinson, W. E., and Bishop, J. M. (1973). RNAdirected DNA synthesis by virions of Rous sarcoma virus: Further characterization of the templates and the extent of their transcription. Virology $\mathbf{5 2}$, 264-273.

Halpern, M. S., Wade E., Rucker, E., BaXterGabbard, R. L., Levine, A., and Friss, R. R. (1973). A study of the relationship of reticuloendotheliosis virus to the avian leukosis-sarcoma complex of viruses. Virology 53, 287-299.

Kieras, R. M., and Faras, A. J. (1975). DNA polymerase of reticuloendotheliosis virus: Inability to detect endogenous RNA-directed DNA synthesis. Virology in press.

KANG, C. Y., and TEMIN, H. M. (1973). Lack of sequence homology among RNA's of avian leukosissarcoma viruses, reticuloendotheliosis viruses and chicken endogenous RNA-directed DNA polymerase activity. J. Virol. 12, 1314-1324.

KANG, C. Y., and TEMIN, H. M. (1974). Reticuloendotheliosis virus nucleic acid sequences in cellular DNA. J. Virol. 14, 1179-1188.
Maldonado, R. L. and Bose, H. R. (1971). Separation of reticuloendotheliosis virus from avian RNA tumor viruses. J. Virol. 8, 813-815.

Maldonado, R. L., and Bose, H. R. (1973). Relationship of reticuloendotheliosis virus to the avian tumor viruses: Nucleic acid and polypeptide composition. J. Virol. 11, 741-747.

McConaughy, B. L., and McCarthy, B. J. (1967). The interaction of oligonucleotides with denatured DNA. Biochim. Biophys. Acta 149, 180-189.

Melli, M., Whitfield, C., Rao, V. K., Ricilardson, M., and Bishop, J. O. (1971). DNA-RNA hybridization in vast DNA excess. Nature New Biol. 231, 8-12.

Mizutani, S., and Temin, H. (1973). Lack of serological relationship among DNA polymerases of avian leukosis-sarcoma viruses, reticuloendotheliosis viruses, and chicken cells. $J$. Virol. 12, 440-448.

Neiman, P. E. (1972). Rous sarcoma virus nucleotide sequences in cellular DNA: Measurement by RNADNA hybridization. Science 178, 750-753.

Neiman, P. E. (1973). Measurement of endogenous leukosis virus nucleotide sequences in the DNA of normal avian embryos by RNA-DNA hybridization. Virology 53, 196-204.

Purchase, G. H., Ludford, C., Nazerian, K., and Cox, H. W. (1973). A new group of oncogenic viruses: Reticuloendotheliosis, chick syncytial, duck infectious anemia, and spleen necrosis viruses. J. Nat. Cancer Inst. 51, 489-497.

Schincariol, A. L., and JokLik, W. E. (1973). Early synthesis of virus-specific RNA and DNA in cells rapidly transformed with Rous sarcoma virus. $V i$ rology 56, 532-548.

Strauss, N. A., and Bonner, T. I. (1972). Temperature dependence of RNA-DNA hybridization kinetics. Biochim. Biophys. Acta 277, 87-95.

Temin, H. M. (1963). The effects of actinomycin D on growth of Rous sarcoma virus in vitro. Virology 20, 577-582.

Temin, H. M. (1967). Studies on carcinogenesis by avian sarcoma viruses. V. Requirement for new DNA synthesis and for cell division. J. Cell Physiol. 69, 53-64.

Temin, H. M. (1969). Control of cell multiplication of uninfected chicken cells converted by avian sarcoma viruses. J. Cell. Physiol. 74, 9-15.

Temin, H. M. (1971a). Mechanism of cell transformation by RNA tumor viruses. Annu. Rev. Microbiol. 25, 609-648.

Temin, H. M. (1971b). Stimulation by serum of multiplication of stationary chicken cells. J. Cell Physiol. 78, 161-170.

Temin, H. M., and Baltimore, D. (1972). RNAdirected DNA synthesis and RNA tumor viruses. In "Advances in Virus Research" (K. M. Smith and M. A. Lauffer eds.), Vol. 17, pp. 129-186. Academic Press, New York. 
Temin, H. M., and Kassner, V. R. (1974). Replication of reticuloendotheliosis viruses in cell culture: Acute infection. J. Virol. 13, 291-297.

Theilen, G. H., Zeigel, R. F., and Twiehaus, M. J. (1966). Biological studies with the RE virus (strain T) that induces reticuloendotheliosis in turkeys, chickens and Japanese quail. J. Nat. Cancer Inst. 37, 731-743.

Varmus, H. E., Vogt, P. K., and Bishop, J. M. (1973). Integration of Rous sarcoma virus-specific DNA following infection of permissive and non-permissive hosts. Proc. Nat. Acad. Sci. USA 70,
3067-3071.

Varmus, H. E., Heasley, S., and Bishur, J. M. (1974). Use of DNA-DNA Annealing to detect new virusspecific DNA sequences in chicken embryo fibroblasts after infection by avian sarcoma virus. $J$. Virol. 14, 895-903.

Zeigel, R. F., Theilen, G. H., and Twiehaus, M. J. (1966). Electron microscopic observations on $\mathrm{RE}$ virus (strain $\mathrm{T}$ ) that induces reticuloendotheliosis in turkeys, chickens, and Japanese quail. J. Nat. Cancer Inst. 37, 709-729. 